\title{
Effect of microrelief and vegetation on methane emission from wet polygonal tundra, Lena Delta, Northern Siberia
}

\author{
LARS KUTZBACH $^{1}{ }^{*}$, DIRK WAGNER ${ }^{1}$ and EVA-MARIA PFEIFFER ${ }^{2}$ \\ ${ }^{1}$ Alfred Wegener Institute Foundation for Marine and Polar Research, Research Unit Potsdam, P.O.B. \\ 600149, D-14401 Potsdam, Germany; ${ }^{2}$ Institute of Soil Science, University of Hamburg, Allende-Platz 2, \\ D-20146 Hamburg, Germany; *Author for correspondence (e-mail: lkutzbach@awi-potsdam.de; phone: \\ $+49-331-288-2142$ )
}

Received 20 May 2003; accepted in revised form 4 September 2003

Key words: Aerenchyma, Carex aquatilis, Methane emission, Microrelief, Plant-mediated gas transport, Polygonal tundra

\begin{abstract}
The effect of microrelief and vegetation on methane $\left(\mathrm{CH}_{4}\right)$ emission was investigated in a wet polygonal tundra of the Lena Delta, Northern Siberia (72.37N, 126.47E). Total and plant-mediated $\mathrm{CH}_{4}$ fluxes were measured by closed-chamber techniques at two typical sites within a low-centred polygon. During the study period, total $\mathrm{CH}_{4}$ flux averaged $28.0 \pm 5.4 \mathrm{mg} \mathrm{m}^{-2} \mathrm{~d}^{-1}$ in the depressed polygon centre and only $4.3 \pm 0.8 \mathrm{mg} \mathrm{m}^{-2} \mathrm{~d}^{-1}$ at the elevated polygon rim. This substantial small-scale spatial variability of $\mathrm{CH}_{4}$ emission was caused by strong differences of hydrologic conditions within the microrelief of the polygon, which affected aeration status and organic matter content of the soils as well as the vegetation cover. Beside water table position, the vegetation cover was a major factor controlling $\mathrm{CH}_{4}$ emission from polygonal tundra. It was shown that the dominant vascular plant of the study area, Carex aquatilis, possesses large aerenchyma, which serve as pathways for substantial plant-mediated $\mathrm{CH}_{4}$ transport. The importance of plant-mediated $\mathrm{CH}_{4}$ flux was strongly influenced by the position of the water table relative to the main root horizon. Plant-mediated $\mathrm{CH}_{4}$ transport accounted for about twothirds of the total flux in the wet polygon centre and for less than one-third of the total flux at the moist polygon rim. A clipping experiment and microscopic-anatomical studies suggested that plant-mediated $\mathrm{CH}_{4}$ transport via $C$. aquatilis plants is driven only by diffusion and is limited by the high diffusion resistance of the dense root exodermes.
\end{abstract}

\section{Introduction}

Northern wetlands play an important role within the global methane $\left(\mathrm{CH}_{4}\right)$ cycle. Recent estimates of the $\mathrm{CH}_{4}$ source strength of northern wetlands, including tundra, range between 17 and $42 \mathrm{Tg} \mathrm{CH}_{4} \mathrm{yr}^{-1}$ or from 3.5 to $8.5 \%$ of the total atmospheric budget (Whalen and Reeburgh 1992; Christensen 1993; Harriss et al. 1993, Roulet et al. 1994; Cao et al. 1996).

Anticipating global warming by an enhanced greenhouse effect, high-latitude ecosystems are expected to warm more rapidly and to a greater extent than the rest of the biosphere (Maxwell 1997; Intergovernmental Panel on Climate Change 2001). To assess the effects of climatic change on the sensitive arctic ecosystems 
with regard to $\mathrm{CH}_{4}$ emission and possible feedbacks to the atmospheric system, it is important to improve the understanding of how the $\mathrm{CH}_{4}$ emission is controlled by the involved environmental variables, soil processes, and microbial communities. $\mathrm{CH}_{4}$ emission from arctic wetlands results from the complex interaction between production, consumption, and transport of $\mathrm{CH}_{4}$. These processes are governed by a set of interrelated environmental factors, including microbial community structure, climatic conditions, soil properties, and vegetation characteristics.

The vegetation occupies a central position in this complex system. Plants can have both enhancing and attenuating effects on $\mathrm{CH}_{4}$ emission. Through the aerenchyma of vascular plants, oxygen is transported from the atmosphere to the rhizosphere, thus stimulating $\mathrm{CH}_{4}$ oxidation in otherwise anoxic soil horizons (Van der Nat and Middelburg 1998; Popp et al. 2000). In opposite direction, the aerenchyma are a major pathway for $\mathrm{CH}_{4}$ transport from the anoxic horizons to the atmosphere, bypassing the oxic/anoxic interface in the soil, where $\mathrm{CH}_{4}$ oxidation is prominent (Sebacher et al. 1985; Holzapfel-Pschorn et al. 1986; Schütz et al. 1991). Furthermore, the vegetation provides the substrates for methanogenesis as decaying plant material and fresh root exudates (Whiting and Chanton 1992; Joabsson et al. 1999). Most studies demonstrated that the enhancing effects of vegetation on $\mathrm{CH}_{4}$ emission exceed the attenuating effects (e.g., Torn and Chapin 1993; Sorrell and Boon 1994; Thomas et al. 1996; King et al. 1998), but several other studies reported converse results (Grünfeld and Brix 1999; RouraCarol and Freeman 1999).

Most studies on the effect of the vegetation on $\mathrm{CH}_{4}$ emission from boreal and arctic ecosystems have been conducted in North America (e.g. Whiting and Chanton 1992; Morrissey et al. 1993; Torn and Chapin 1993; Schimel 1995; Waddington et al. 1996; Kelker and Chanton 1997; King et al. 1998). Despite an increasing number of studies on $\mathrm{CH}_{4}$ fluxes from the vast wetlands of Siberia published in the last decade (Panikov et al. 1993; Christensen et al. 1995; Samarkin et al. 1999; Nakano et al. 2000; Wagner et al. 2003), only one investigation on the effect of vegetation on $\mathrm{CH}_{4}$ emission from Siberian tundras has been reported so far (Tsuyuzaki et al. 2001).

This paper examines the effect of microrelief and vegetation on the small-scale variability of $\mathrm{CH}_{4}$ emission from arctic wet polygonal tundra of the Lena Delta, Northern Siberia. Research focused on the plant-mediated $\mathrm{CH}_{4}$ emission via individual culms of Carex aquatilis Wahlenb., the dominant vascular plant species of the examined tundra landscape. In detail, the purposes of this study were:

- to investigate the effects of microrelief and soil characteristics on the total (soil + plant-mediated) $\mathrm{CH}_{4}$ flux from wet polygonal tundra;

- to assess the amount of plant-mediated $\mathrm{CH}_{4}$ flux via the aerenchyma of $C$. aquatilis and its contribution to the total $\mathrm{CH}_{4}$ flux;

- to examine the response of plant-mediated $\mathrm{CH}_{4}$ flux to differing microtopography and hydrologic conditions;

- to get further information about the mechanism of gas transport through $C$. aquatilis. 


\section{Study site}

Within the scope of the joint Russian-German project 'System Laptev Sea 2000', an expedition was undertaken in August 1999 to the Lena Delta, Northern Siberia (Rachold and Grigoriev 2000). Field work was conducted on Samoylov, a typical island of the central part of the delta $(72.37 \mathrm{~N}, 126.47 \mathrm{E})$. The Lena Delta with an area of $28,000 \mathrm{~km}^{2}$ is one of the largest deltas in the world. It is located in the zone of continuous permafrost. The climate is true-arctic, continental, and characterised by very low temperatures and low precipitation. The mean annual temperature is $-10.2^{\circ} \mathrm{C}$, and the mean annual precipitation amounts to $140 \mathrm{~mm}$ (Müller 1997). The topography of the Lena Delta is flat, but well-structured by a prominent microrelief caused by the development of low-centred ice-wedge polygons. The depressed centres of these polygons are surrounded by elevated rims, which are situated above the ice-wedges. The polygon centres contribute about $45 \%$ and the rims about $55 \%$ to the total area of the polygonal tundra in the study area.

The investigation sites of this study were located within a typical low-centred polygon with a diameter of about $20 \mathrm{~m}$. One investigation site was established in the polygon centre and the other at the polygon rim. Distance between these two sites was $10 \mathrm{~m}$. The soil surface at the polygon rim was about $0.5 \mathrm{~m}$ higher than in the polygon centre. Wooden boardwalks were set up to minimise disturbance of the soils during investigations.

\section{Methods}

Characterisation of vegetation and soils

The vegetation of the polygonal tundra was investigated according to the phytosociological approach of Braun-Blanquet (1964). The plant communities of the elevated rim and the depressed centre of the polygon were described at plots of $2 \mathrm{~m}^{2}$. Vascular plants were identified using Polunin (1959), mosses and lichens were identified by means of a reference herbarium provided by M.P. Zhurbenko and I.V. Czernyadeva (Komarov Botanical Institute, St. Petersburg). Species dominance was estimated as the percentage of basal area that was covered by the species.

The soils of the two study sites were described and sampled in small pits. Texture, colour, and quantity of roots in individual soil horizons were surveyed according to Schoeneberger et al. (1998). Redox status was characterised by means of $\alpha$ - $\alpha^{\prime}$-dipyridyl solution (Soil Survey Staff 1998), which was sprayed on freshly broken surfaces of field-wet soils. The reagent complexes ferrous iron to a complex which has a distinctive red colour. By proving the presence of soluble reduced iron ions, a positive $\alpha-\alpha^{\prime}$-dipyridyl test indicates watersaturated and anoxic soil conditions. Bulk density, content of organic carbon and total nitrogen of soil samples were determined in the laboratory according to Schlichting et al. (1995). Soils were classified according to US Soil Taxonomy (Soil Survey Staff 1998) and the Russian system of Elovskaya (1987). 
a

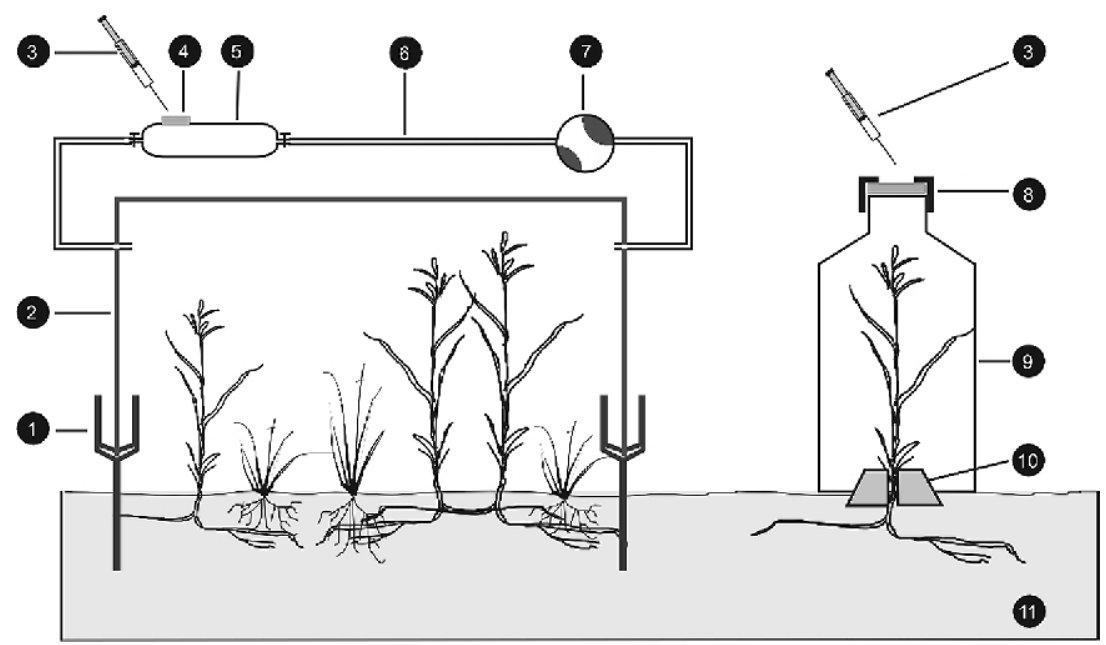

Figure 1. Design of different $\mathrm{CH}_{4}$ flux chambers. (a) Total flux chamber, (b) plant-mediated transport chamber. Legend: 1, steel base with water-filled channel (permanently installed); 2, PVC top (removable); 3, syringe; 4, septum; 5, glass vessel; 6, tubing; 7, membrane pump; 8, cap with septum; 9 , glass bottle; 10, rubber stopper with central channel; 11, soil.

Simultaneously to the $\mathrm{CH}_{4}$ flux measurements described below, soil conditions were recorded at each site as follows: depth of permafrost table was measured by driving a steel rod into the unfrozen soil until the hard frozen sediments were encountered. Water table was measured in perforated plastic pipes, which were installed in the soil active layer. Soil temperatures were recorded automatically at soil depths of 15 and $30 \mathrm{~cm}$ by thermistor probes (Campbell Scientific, Type 107) and a datalogger (Campbell Scientific Inc., CR10X).

\section{$\mathrm{CH}_{4}$ flux measurements}

Three $\mathrm{CH}_{4}$ flux experiments were conducted in August 1999:

(1) To provide a comparison between total (soil + plant-mediated) $\mathrm{CH}_{4}$ flux and plant-mediated $\mathrm{CH}_{4}$ flux, these fluxes were simultaneously determined by two different types of closed-chamber techniques. Measurements were conducted daily at midday during the period 9 August - 1 September (21 measurement days). At each site, three total-flux chambers (Figure 1(a)) and nine plant flux chambers (Figure 1(b)) were installed closely to each other within an area of $2 \mathrm{~m} \times 1 \mathrm{~m}$. Since $C$. aquatilis was the only aerenchymatous plant with a relevant dominance at the study site, examination of plant-mediated $\mathrm{CH}_{4}$ transport was restricted to $C$. aquatilis. 
(2) In the period 7-10 August, seven additional total-flux chambers were used at the investigated polygon (overall eight chambers in the centre and five at the rim). Obtained total $\mathrm{CH}_{4}$ fluxes were related to areal densities of Carex culms, which were determined by counting the culms on the area that was covered by the chambers.

(3) To get further information about the mechanism of plant-mediated $\mathrm{CH}_{4}$ transport by $C$. aquatilis, a clipping experiment was conducted: at midday of 26 August, plant-mediated $\mathrm{CH}_{4}$ fluxes through eight plants in the polygon centre were measured before and after clipping plants at the base of the culms $5 \mathrm{~cm}$ above the soil surface.

The total-flux chambers consisted of permanently installed bases of stainless steel and removable tops made of $6 \mathrm{~mm}$ thick, transparent PVC plates (Figure 1(a)). The chamber bases had the dimensions $0.5 \mathrm{~m} \times 0.5 \mathrm{~m} \times 0.15 \mathrm{~m}$ and isolated $0.25 \mathrm{~m}^{2}$ of soil surface. The walls of the bases were inserted carefully in pre-cut grooves in the soil to a depth of $0.15 \mathrm{~m}$ at well-drained sites and $0.05 \mathrm{~m}$ at waterlogged sites, respectively. The chamber tops had the dimensions $0.5 \mathrm{~m} \times 0.5 \mathrm{~m} \times 0.05 \mathrm{~m}$. For sample drawing, the chamber tops were sealed to the bases by a water-filled channel running around the top of each base. Air volume inside the chambers ranged from 12.51 to 37.51 depending on water table position. Flow-through circulation was provided by a small membrane pump connected with the chambers by Tygon ${ }^{\circledR}$ tubing. After 30 min deployment, gas samples were taken by means of glass vessels, which were integrated in the gas circulation system and could be sealed by taps.

For determination of plant-mediated $\mathrm{CH}_{4}$ flux, special closed chambers were used, in which single culms of $C$. aquatilis could be enclosed (Figure 1(b)). The chambers were 0.5-1 and 1.0-1 glass bottles with a rubber septum put in the cap. In the bottom of the bottle was a hole, in which a rubber stopper could be fitted. For sample drawing, a rubber stopper with a hole drilled out and slit down the side was wrapped around the base of an individual plant culm. The chamber was then placed over the plant and onto the rubber stopper, sealing the system. After 30-60 min deployment 5-ml samples of the headspace gas were withdrawn through the septum with a gas-tight syringe and transferred into $10-\mathrm{ml}$ glass tubes filled with saturated sodium chloride solution and sealed with rubber stoppers and twisted caps. The saturated sodium chloride solution prevented microbial activity and minimised solution processes of gases (Heyer and Suckow 1985).

In parallel to the deployment of chambers, ambient air was sampled directly above the soil surface. The $\mathrm{CH}_{4}$ concentration of ambient air was used as an estimate for initial $\mathrm{CH}_{4}$ concentrations in the chambers. To prove the reasonability of this estimation and the linearity of $\mathrm{CH}_{4}$ accumulation with time, a series of test experiments ( $n=6$ for each chamber type) were performed. Samples were drawn from the chambers at four points in time after sealing, at $t_{1}=10 \mathrm{~min}, t_{2}=20 \mathrm{~min}$, $t_{3}=30 \mathrm{~min}$, and $t_{4}=60 \mathrm{~min}$. The accumulation of $\mathrm{CH}_{4}$ with time was analysed by least-square linear regression. During all tests, $\mathrm{CH}_{4}$ accumulation was profoundly linear $(r>0.998)$. Comparing the slopes of the linear regression lines with the 
two-point lines between ambient air and final chamber concentration, revealed an error of $\pm 5 \%$ introduced by applying the simplified two-point method.

Irregular release of $\mathrm{CH}_{4}$ by bubbling was considered to be unlikely at the investigated tundra site because the water table was below the soil surface and the soil is densely vegetated. Under these conditions, the main gas transport process is diffusion, either through the soil pore system or via the aerenchyma of the wetland plants (Holzapfel-Pschorn et al. 1986; Chanton and Dacey 1991; Schütz et al. 1991).

\section{Gas chromatography}

$\mathrm{CH}_{4}$ concentrations in samples were analysed within $12 \mathrm{~h}$ of collection with a gas chromatograph (Chrompack, GC 9003) in the field laboratory. $\mathrm{CH}_{4}$ was separated on a PoraPLOT Q capillary column (100/120 mesh, $20 \mathrm{~m}$, Chrompack) operating at $80{ }^{\circ} \mathrm{C}$ with helium as carrier gas and was detected by a flame ionisation detector. The gas chromatograph was calibrated with standard gases. Measurement accuracy was $2 \%$ for $\mathrm{CH}_{4}$ concentrations of $10 \mathrm{ppm}$. Sample concentrations ranged between 1.7 and $28 \mathrm{ppm}$.

\section{Calculations}

$\mathrm{CH}_{4}$ concentration measurements obtained from samples which were stored in glass tubes filled with $\mathrm{NaCl}$ solution were corrected for the systematic underestimation of $\mathrm{CH}_{4}$ concentrations introduced by the partition of $\mathrm{CH}_{4}$ between the aqueous and the gaseous phase as follows:

$$
C_{\text {corr }}=C_{\text {orig }} * \frac{C_{\text {orig }} * V_{\mathrm{H}}+C_{\text {orig }} * \beta * V_{\mathrm{NaCl}}}{C_{\text {orig }} * V_{\mathrm{H}}},
$$

where $C_{\text {corr }}$ is the corrected $\mathrm{CH}_{4}$ concentration value, and $C_{\text {orig }}$ is the $\mathrm{CH}_{4}$ concentration measured originally in the headspace above the $\mathrm{NaCl}$ solution in the tube. $\beta$ is the solubility of $\mathrm{CH}_{4}$ in saturated sodium chloride solution $\left(0.00867 \mathrm{ml} \mathrm{ml}^{-1}\right.$ at $20^{\circ} \mathrm{C}$; Yamamoto et al. 1976; Seibt et al. 2000). $V_{\mathrm{H}}$ is the volume of the headspace, and $V_{\mathrm{NaCl}}$ is the volume of the $\mathrm{NaCl}$ solution. Since $V_{H}$ and $V_{\mathrm{NaCl}}$ were equal $(5 \mathrm{ml})$ in our experimental setup, Equation (1) can be rewritten as:

$$
C_{\text {corr }}=C_{\text {orig }} *(1+\beta)=C_{\text {orig }} * 1.00867 \text {. }
$$

$\mathrm{CH}_{4}$ fluxes were calculated from the increase of $\mathrm{CH}_{4}$ concentration in the enclosures using the following equation:

$$
F=\frac{C_{t}-C_{a}}{t} * \frac{p * V * M}{R * T}
$$

where $F$ is the mass flux of $\mathrm{CH}_{4}, C_{t}$ is the measured volume/volume $\mathrm{CH}_{4}$ concentration in the chamber after the respective deployment time $t$, and $C_{\mathrm{a}}$ is the $\mathrm{CH}_{4}$ 
Table 1. Vegetation composition in the depressed centre of a low-centred polygon, Samoylov, Lena Delta.

\begin{tabular}{lllll}
\hline Vascular plants stratum (height $30 \mathrm{~cm}$ ) & & \multicolumn{2}{l}{ Moss- and lichen stratum (height 5 cm) } \\
\cline { 5 - 5 } Species & Dominance & & Species & Dominance $^{1}$ \\
\hline Total & $30 \%$ & Total & $95 \%$ \\
Carex aquatilis & $25 \%$ & & Limprichtia revolvens & $25 \%$ \\
C. rariflora & $3 \%$ & Meesia longiseta & $20 \%$ \\
Arctagrostis latifolia & + & Calliergon megalophyllum & $20 \%$ \\
Caltha palustris & + & Drepanocladus exannulatus & $15 \%$ \\
Cardaminopsis tenuifolia & + & Calliergon giganteum & $5 \%$ \\
Saxifraga cernua & + & Meesia triquetra & $5 \%$ \\
Luzula confusa & $\mathrm{r}$ & Abietinella abietina & ++ \\
Equisetum variegatum & $\mathrm{r}$ & Aulacomnium palustre & ++ \\
Pedicularis sudetica & $\mathrm{r}$ & A. turgidum & ++ \\
Polygonum viviparum & $\mathrm{r}$ & Campylium stellatum & ++ \\
Salix glauca & $\mathrm{r}$ & Cinclidium latifolium & ++ \\
S. reptans & $\mathrm{r}$ & Cirriphyllum cirrosum & ++ \\
& & Tomentypnum nitens & + \\
\hline
\end{tabular}

${ }^{1}++$ : domianance $0.5-1.0 \%$; + : dominance $<0.5 \%$; r: sporadic.

concentration of ambient air, which served as an estimate of initial $\mathrm{CH}_{4}$ concentration in the chambers. $M$ is the molecular weight of $\mathrm{CH}_{4}, p$ is the barometric pressure, and $V$ is the volume of the chamber. $T$ is the air temperature $(\mathrm{K})$, and $R$ is the universal gas constant.Total $\mathrm{CH}_{4}$ fluxes were referred to the area of soil surface from which the gas is emitted into the total-flux chamber. Estimated plant-mediated $\mathrm{CH}_{4}$ flux on an areal basis was calculated by multiplying the average flux from Carex culms $(n=9$ at each site) by the average areal density of Carex culms in the total-flux chambers $(n=3$ at each site).

\section{Anatomical studies of $\mathrm{C}$. aquatilis}

For anatomical characterisation of the aerenchyma of $C$. aquatilis, cross-sections of rhizomes, roots, and shoots of $C$. aquatilis were dissected with a razor blade. The sample pieces were dehumidified in an ascending ethanol sequence and then dried in a critical point dryer (BAL-TEC, CPD 030). They were coated with an approximately $50 \mathrm{~nm}$ thick gold film (BAL-TEC, SCD 050) and examined with a scanning electron microscope (Phillips, XL-20) at an accelerating voltage of $15 \mathrm{keV}$.

\section{Results}

Vegetation composition of the low-centred polygon

The vegetation at the study sites, in the polygon centre (Table 1) as well as at the polygon rim (Table 2), was composed of two strata: a moss/lichen layer of about 
Table 2. Vegetation composition at the summit of the elevated rim of a low-centred polygon, Samoylov, Lena Delta.

\begin{tabular}{|c|c|c|c|}
\hline \multicolumn{2}{|c|}{ Vascular plants stratum (height: $20 \mathrm{~cm}$ ) } & \multicolumn{2}{|c|}{ Moss- and lichen stratum (height: $5 \mathrm{~cm}$ ) } \\
\hline Species & Dominance $^{1}$ & Species & Dominance $^{1}$ \\
\hline Total & $30 \%$ & Total & $95 \%$ \\
\hline Carex aquatilis & $8 \%$ & Hylocomium splendens & $70 \%$ \\
\hline Dryas octopetala & $6 \%$ & Timmia austriaca & $7 \%$ \\
\hline Astragalus frigidus & $3 \%$ & Climacium dendroides & $2 \%$ \\
\hline Salix glauca & $3 \%$ & Distichium cappilaceum & $2 \%$ \\
\hline S. reptans & $1 \%$ & Tomentypnum nitens & $2 \%$ \\
\hline Lagotis glauca & ++ & Sanionia uncinata & $1 \%$ \\
\hline Luzula confusa & ++ & & \\
\hline L. nivalis & ++ & Peltigera aphtosa & $5 \%$ \\
\hline Poa arctica & ++ & Stereocaulon alpinum & $2 \%$ \\
\hline Pyrola rotundifolia & ++ & Cetraria laevigata & $1 \%$ \\
\hline Trisetum sibiricum & ++ & Dactylina arctica & $1 \%$ \\
\hline Polygonum viviparum & + & Flavocetraria cucullata & $1 \%$ \\
\hline Saxifraga hirculus & + & Peltigera sp. & $1 \%$ \\
\hline Koeleria asiatica & $\mathrm{r}$ & Cladonia pyxidata & ++ \\
\hline Papaver radicatum & $\mathrm{r}$ & & \\
\hline Saxifraga сегnиа & $\mathrm{r}$ & & \\
\hline Stellaria sp. & $\mathrm{r}$ & & \\
\hline
\end{tabular}

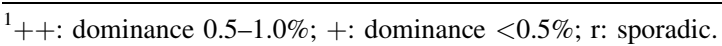

$5 \mathrm{~cm}$ height and a vascular plant layer of $20-30 \mathrm{~cm}$ height. Whereas the total coverage of the moss/lichen layer was high with $95 \%$, the total coverage of vascular plants was rather small with maximal $30 \%$. The dominating vascular plant species at both sites was the sedge $C$. aquatilis. Its dominance was $25 \%$ in the polygon centre and $8 \%$ at the polygon rim. The density of $C$. aquatilis averaged 240 culms $\mathrm{m}^{-2}$ in the centre and $72 \mathrm{culms} \mathrm{m}^{-2}$ at the rim. The vegetation in the polygon centre (Table 1) could be assigned to the phytosociological association Meesio triquetris-Caricetum stantis (Matveyeva 1994). The vegetation at the polygon rim (Table 2) was considered to be a transient type between the associations $M$. triquetris-C. stantis and Carici arctisibiricae-Hylocomietum alaskinii. The latter was described as the typical 'zonal' association for Northern Siberia by Matveyeva (1994). Despite the over-all dominance of $C$. aquatilis, a pronounced vegetation zonation along the microtopographical gradient could be observed regarding species composition and dominance ratios. Most of the species that grew on the rim were not found in the polygon centre and vice versa. While the vegetation of the polygon centre was composed exclusively of hydrophytes like $C$. aquatilis and the mosses Limprichtia revolvens and Meesia longiseta, at the polygon rim mesophytes like the dwarf shrub Dryas octopetala and the mosses Hylocomium splendens and Timmia austriaca had high dominances. 


\section{Soil conditions}

Soil conditions varied greatly between plots at the elevated polygon rim and the depressed polygon centre (Table 3). The soils in the polygon centre were characterised by permafrost-induced waterlogging, predominantly reducing conditions in the pedon, anaerobic accumulation of organic matter, a sandy texture of the mineral soil, and the absence of cryoturbation. They were classified as Typic Historthels according to US Soil Taxonomy and as Permafrost Peat-Gleys according to the Russian system. By contrast, the soils of the polygon rim were characterised by a distinctly deeper water table, oxic conditions in the top soil, lower content of organic matter, a loamy soil texture, and pronounced cryoturbation properties. These soils were classified as Typic Aquiturbels (US Soil Taxonomy) and Permafrost Turf Gleys (Russian system), respectively. The main root horizon of the Typic Historthels of the polygon centre was situated in the water saturated soil zone with reducing conditions (OeBg, $11-26 \mathrm{~cm}$, Table 3(a)). In the OeBg horizon, C. aquatilis had produced a dense mat of thick rhizomes, coarse perennial roots and a mass of fine branching roots. In the Typic Aquiturbels of the polygon rim, the main root horizon was situated in the oxic top soil $(\mathrm{Ajj}, 0-15 \mathrm{~cm})$ while rooting density in the deeper horizons with reducing conditions was low (Table 3(b)).

During August 1999, permafrost table and water table did not show high temporal variation. In the Typic Historthel of the polygon centre, the permafrost table dropped gradually from 33.5 to $37.5 \mathrm{~cm}$ below soil surface, and the water table ranged between 0 and $4.5 \mathrm{~cm}$ below soil surface (Figure 2(b)). In the Typic Aquiturbel of the polygon rim, the permafrost table dropped from 36 to $40 \mathrm{~cm}$ below soil surface, and the water table was always situated directly (about $1 \mathrm{~cm}$ ) above the permafrost table (Figure 3(b)). The soil temperature varied substantially during the study period. In the polygon centre, soil temperature $15 \mathrm{~cm}$ below soil surface ranged between 1.6 and $6.7^{\circ} \mathrm{C}$ and averaged $3.6 \pm 1.3{ }^{\circ} \mathrm{C}$; temperature at $30 \mathrm{~cm}$ depth averaged $2.0 \pm 0.7^{\circ} \mathrm{C}$ (Figure 2(c)). At the polygon rim, soil temperature at $15 \mathrm{~cm}$ depth ranged between $2.6^{\circ} \mathrm{C}$ and $7.6^{\circ} \mathrm{C}$ and averaged $4.7 \pm 1.4^{\circ} \mathrm{C}$; temperature at $30 \mathrm{~cm}$ depth averaged $3.4 \pm 1.0^{\circ} \mathrm{C}$ (Figure 3(c)).

\section{$\mathrm{CH}_{4}$ fluxes}

The strongly differing soil conditions at the centre and the rim of the polygon were reflected by the total (soil + plant-mediated) $\mathrm{CH}_{4}$ fluxes. During the study period, total $\mathrm{CH}_{4}$ flux averaged $28.0 \pm 5.4 \mathrm{mgCH}_{4} \mathrm{~m}^{-2} \mathrm{~d}^{-1}$ in the polygon centre and only $4.3 \pm 0.8 \mathrm{mg} \mathrm{CH}_{4} \mathrm{~m}^{-2} \mathrm{~d}^{-1}$ at the polygon rim (Table 4). Within each site, temporal variability of total $\mathrm{CH}_{4}$ flux was relatively low with only a few outliers (Figures 2(a) and Figure 3(a))

Plant-mediated $\mathrm{CH}_{4}$ flux via culms of $C$. aquatilis was of higher importance in the polygon centre than at the polygon rim. At the polygon centre, the estimated proportion of plant-mediated $\mathrm{CH}_{4}$ flux ranged between 37 and $102 \%$ and averaged $66 \pm 20 \%$ of the total emission (Figure 2(a), Table 4). At the polygon rim it ranged 
350

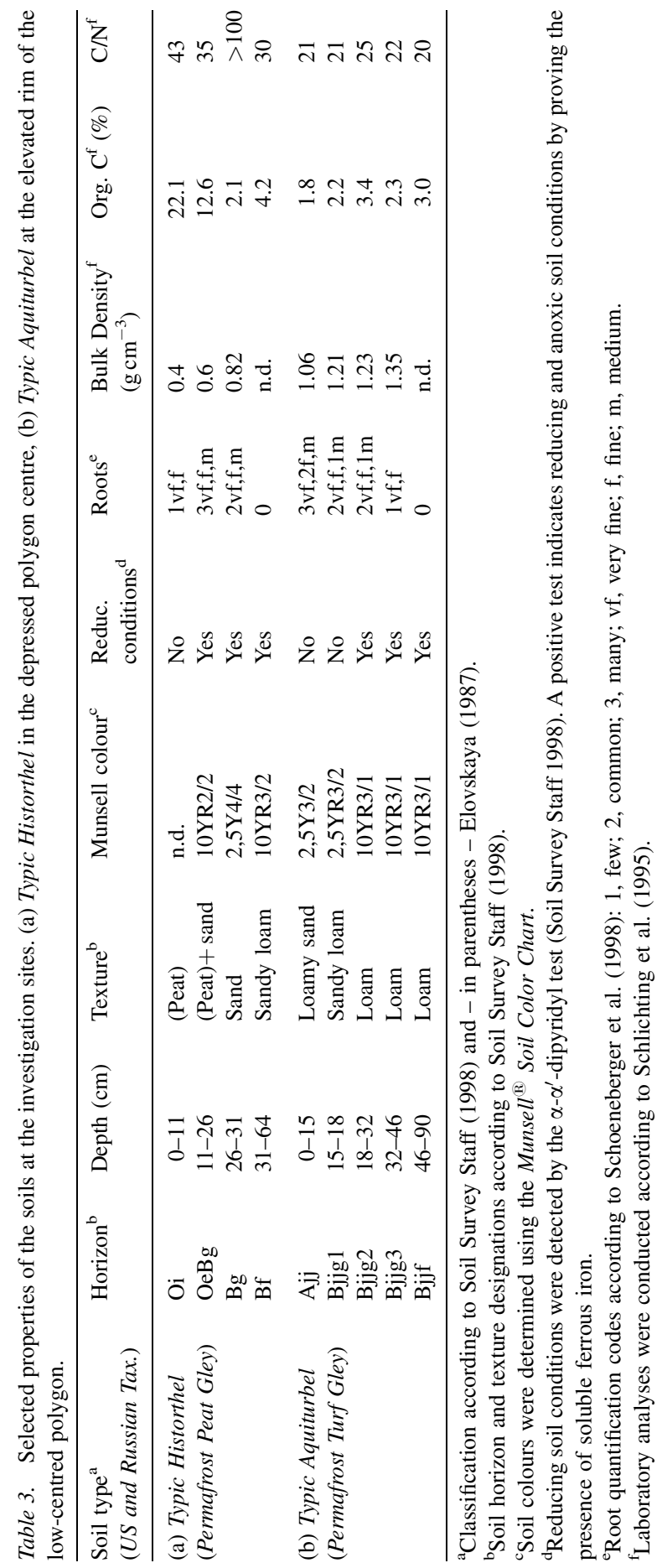


a

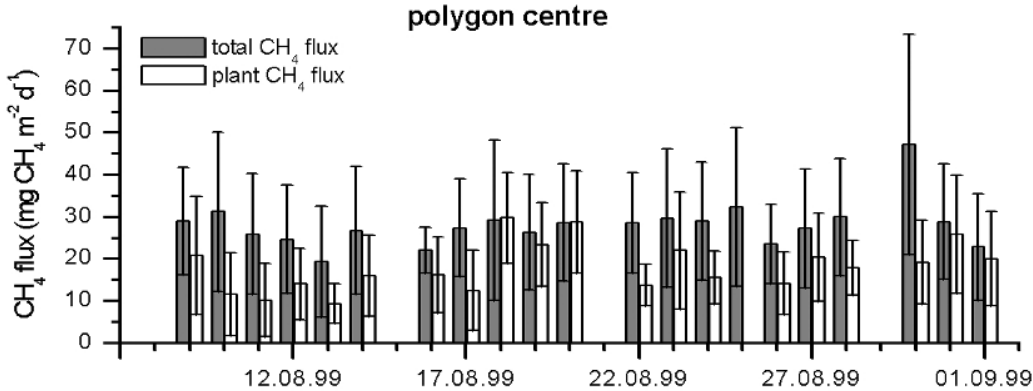

b
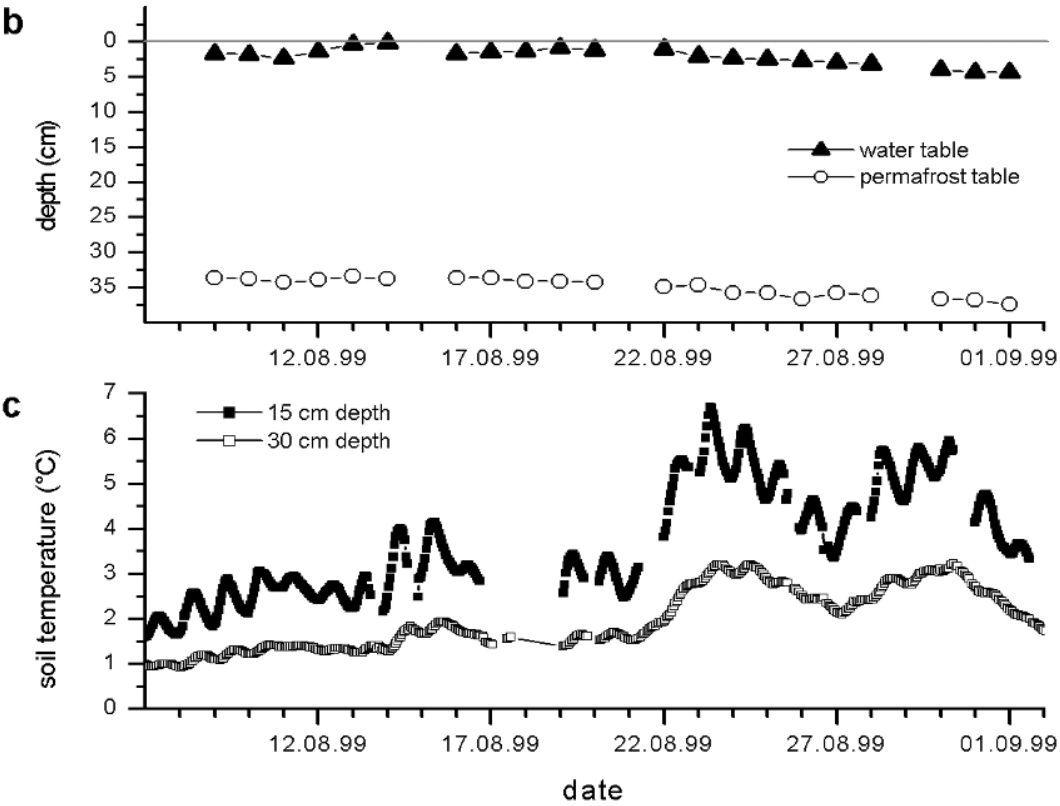

Figure 2. $\mathrm{CH}_{4}$ fluxes and soil conditions in the centre of a low-centred polygon, Lena Delta, Northern Siberia, August 1999. (a) Total $\mathrm{CH}_{4}$ flux (grey columns) and estimated plant-mediated $\mathrm{CH}_{4}$ flux (white columns). Each total flux column represents the average of fluxes from three $0.25-\mathrm{m}^{2}$-plots. Estimated plant-mediated $\mathrm{CH}_{4}$ flux on an areal basis was calculated by multiplying the average flux from individual C. aquatilis culms $(n=9)$ by the average areal density of $C$. aquatilis culms in the total-flux chambers $(n=3)$. (b) Depth of water table (triangles) and permafrost table (circles) measured from soil surface. (c) Soil temperature at depths of $15 \mathrm{~cm}$ (filled squares) and $30 \mathrm{~cm}$ (open squares).

between 12 and $39 \%$ and averaged only $27 \pm 9 \%$ of the total emission (Figure 3(a), Table 4).

Total $\mathrm{CH}_{4}$ fluxes were strongly dependent on areal density of $C$. aquatilis culms. A positive correlation between culm density and total $\mathrm{CH}_{4}$ flux was found for the plots in the polygon centre. The respective least-square regression line was described by the linear function: $\mathrm{CH}_{4}$ emission $=0.23 \mathrm{mg} \mathrm{CH}_{4} \mathrm{~d}^{-1} \dot{\mathrm{c}} \mathrm{culm}$ density 
a

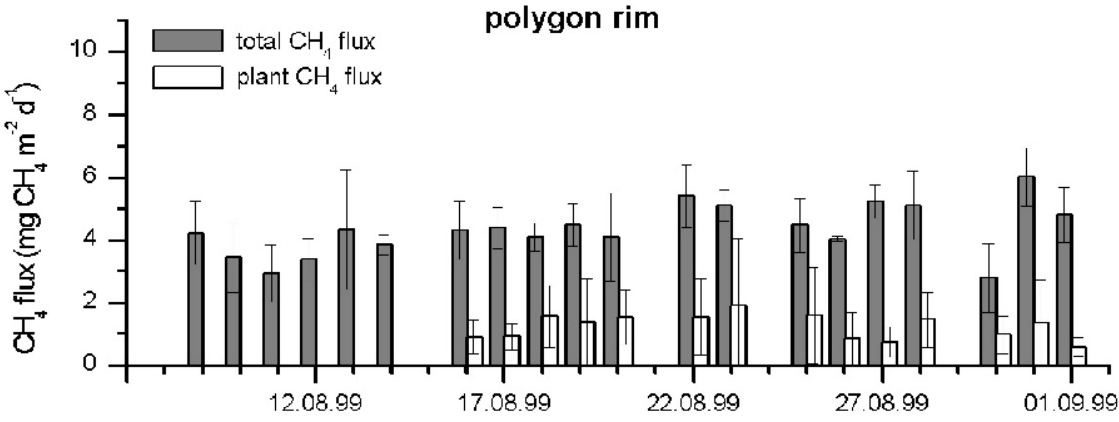

b

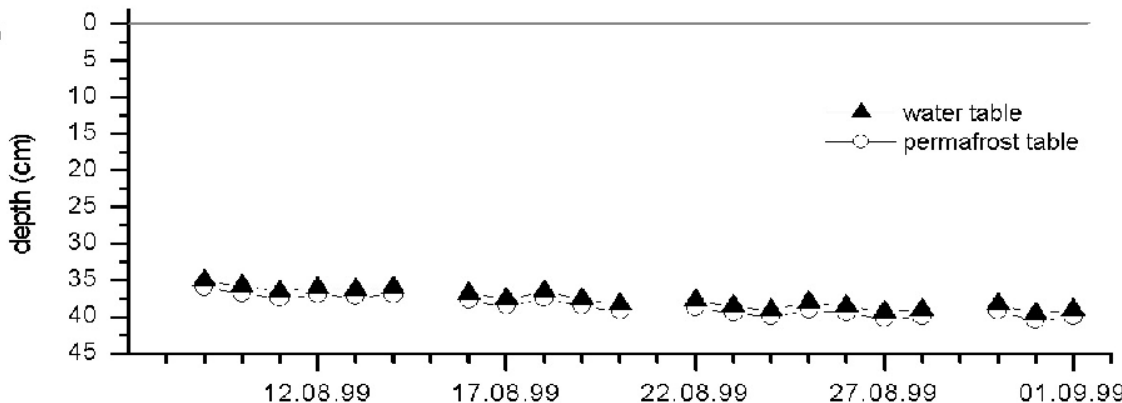

C

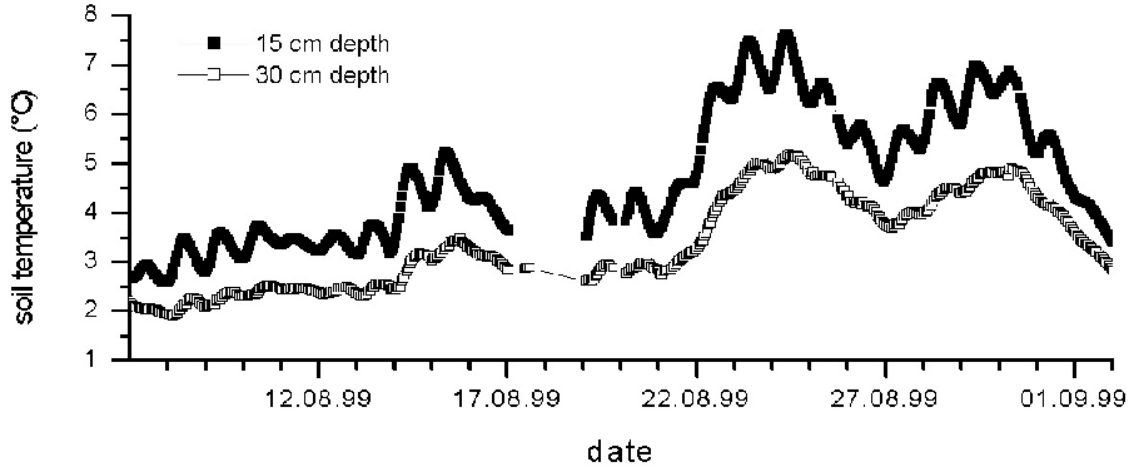

Figure 3. $\mathrm{CH}_{4}$ fluxes and soil conditions at the rim of a low-centred polygon, Lena Delta, Northern Siberia, August 1999. (a) Total $\mathrm{CH}_{4}$ flux (grey columns) and estimated plant-mediated $\mathrm{CH}_{4}$ flux (white columns). Each total flux column represents the average of fluxes from three $0.25-\mathrm{m}^{2}$-plots. Estimated plant-mediated $\mathrm{CH}_{4}$ flux on an areal basis was calculated by multiplying the average flux from individual C. aquatilis culms $(n=9)$ by the average areal density of $C$. aquatilis culms in the total-flux chambers $(n=3)$. (b) Depth of water table (triangles) and permafrost table (circles) measured from soil surface. (c) Soil temperature at depths of $15 \mathrm{~cm}$ (filled squares) and $30 \mathrm{~cm}$ (open squares).

$-30.39 \mathrm{mg} \mathrm{CH}_{4} \mathrm{~d}^{-1} \mathrm{~m}^{-2}(r=0.88, p=0.004, n=8)$. By contrast, a negative correlation between these variables was observed for the plots at the polygon rim. The respective regression line was described by the linear function: $\mathrm{CH}_{4}$ emission $=$ $-0.04 \mathrm{mg} \mathrm{CH}_{4} \mathrm{~d}^{-1} \dot{\mathrm{c}}$ culm density $+6.92 \mathrm{mg} \mathrm{CH}_{4} \mathrm{~d}^{-1} \mathrm{~m}^{-2}(r=-0.97, p=0.006$, $n=5)$. 
Table 4. Total $\mathrm{CH}_{4}$ flux and portion of plant-mediated $\mathrm{CH}_{4}$ transport in wet polygonal tundra. Measurements were conducted in August 1999 on Samoylov Island (72.23N, 126.29E), Lena Delta, Northern Siberia.

\begin{tabular}{|c|c|c|c|c|c|c|c|c|}
\hline \multirow[t]{2}{*}{ Site } & \multicolumn{4}{|c|}{ Total flux $\left(\mathrm{mg} \mathrm{m}^{-2} \mathrm{~d}^{-1}\right)^{\mathrm{a}}$} & \multicolumn{4}{|c|}{ Estimated portion of plant transport $(\%)^{b}$} \\
\hline & Min & $\operatorname{Max}$ & Mean & $n$ & Min & $\operatorname{Max}$ & Mean & $n$ \\
\hline Centre & 19.2 & 47.2 & $28.0 \pm 5.4$ & 21 & 37 & 102 & $66 \pm 20$ & 20 \\
\hline Rim & 2.8 & 6.0 & $4.3 \pm 0.8$ & 20 & 12 & 38 & $27 \pm 9$ & 14 \\
\hline
\end{tabular}

${ }^{a}$ Total (soil + plant-mediated) $\mathrm{CH}_{4}$ flux was measured by three closed chambers at each site with a footprint of $0.25 \mathrm{~m}^{2}$. The given values are minimums, maximums, means and standard deviations of daily means. $n$ is number of measurement days.

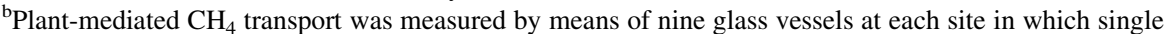
Carex culms could be enclosed. The portion of plant-mediated $\mathrm{CH}_{4}$ flux on an areal basis was estimated by multiplying the average flux through individual Carex culms by the average density of Carex culms in the total-flux chambers and setting the resulting value in relation to the total flux. The given values are minimums, maximums, means and standard of daily means. $n$ is number of measurement days.

Table 5. Effect of clipping culms on plant-mediated $\mathrm{CH}_{4}$ transport via $C$. aquatilis. $\mathrm{CH}_{4}$ fluxes through eight individual culms were measured before and after clipping $5 \mathrm{~cm}$ above the soil surface. The experiment was conducted at midday of 26 August.

\begin{tabular}{llll}
\hline No. & $\begin{array}{l}\mathrm{CH}_{4} \text { flux before } \\
\text { clipping }\left(\mathrm{mg} \mathrm{d}^{-1}\right)\end{array}$ & $\begin{array}{l}\mathrm{CH}_{4} \text { flux after } \\
\text { clipping }\left(\mathrm{mg} \mathrm{d}^{-1}\right)\end{array}$ & $\begin{array}{l}\text { Quotient after/ } \\
\text { before clipping }\end{array}$ \\
\hline 1 & 0.051 & 0.041 & 0.80 \\
2 & 0.073 & 0.067 & 0.91 \\
3 & 0.027 & 0.031 & 1.14 \\
4 & 0.076 & 0.076 & 1.00 \\
5 & 0.051 & 0.044 & 0.87 \\
6 & 0.069 & 0.061 & 0.89 \\
7 & 0.037 & 0.042 & 1.13 \\
8 & 0.057 & 0.061 & 1.08 \\
Mean & & & $0.98 \pm 0.13$ \\
\hline
\end{tabular}

Clipping the culms $5 \mathrm{~cm}$ above the soil surface did not alter the amount of plantmediated $\mathrm{CH}_{4}$ flux by $C$. aquatilis significantly (Table 5).

Aerenchyma in vegetative organs of $\mathrm{C}$. aquatilis

Extensive air spaces or lacunae (=aerenchyma) were observed in all vegetative organs of $C$. aquatilis by scanning electron microscopy (Figure 4). In particular, the extent of the lacunae in the fine roots of $C$. aquatilis was remarkable (Figure 4(a)): With the exception of a few regular arranged radial cell lines and the radial cell walls, the complete root cortex parenchyma was disintegrated and transformed into a large aerenchyma. The large aerenchyma was separated from the rhizosphere by a 
a

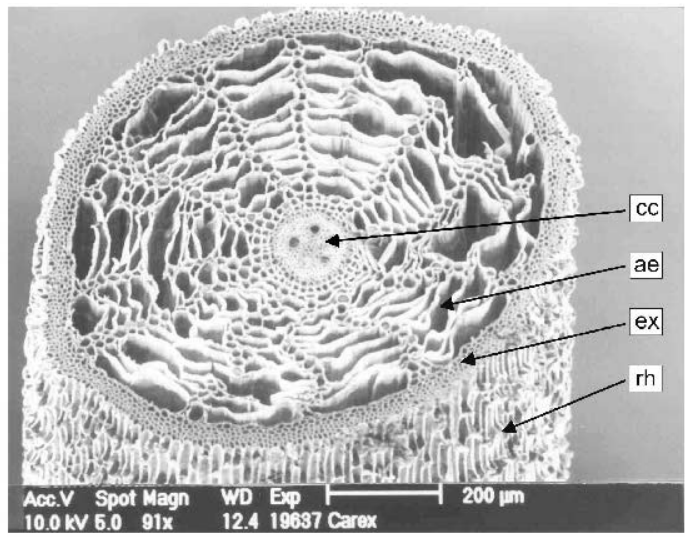

b

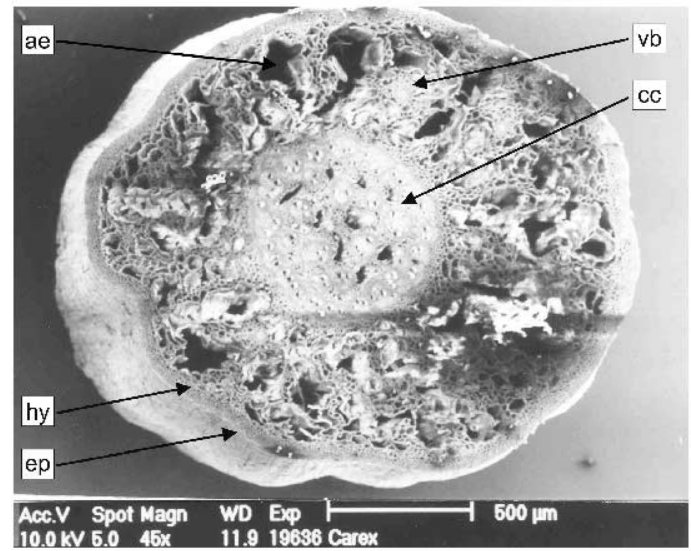

C

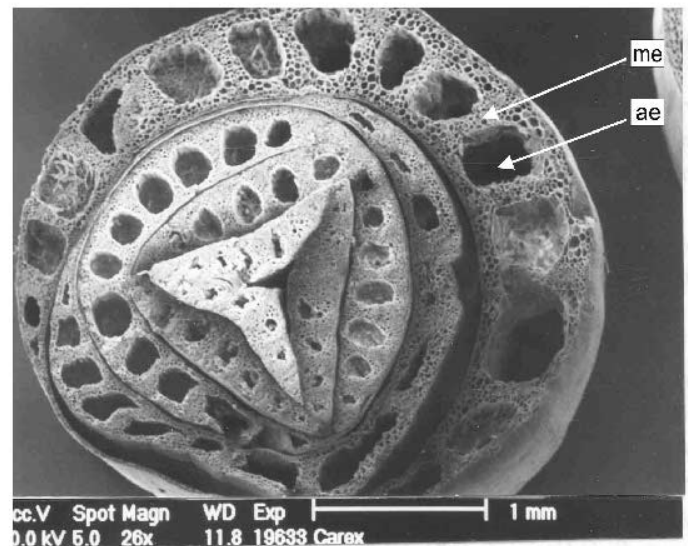

Figure 4. Transverse sections of vegetative organs of $C$. aquatilis Wahlenb. observed by scanning electron microscopy. (a) fine root, (b) rhizome, (c) culm (built up of nested leave sheaths). Legend: ae, aerenchyma; cc, central cylinder; ep, epidermis; ex, exodermis; hy, hypodermis; me, mesenchyme; rh, rhizodermis; vb, vascular bundle. 
dense exodermis, which was built up of compactly packed hexagonal cells with thickened cell walls. In the rhizomes, lacunae were observed in the inner cortex (Figure 4(b)). They were less regular arranged and not as extensive as in the roots. In the leaves sheaths that build up the culms, large lacunae were observed that were embedded in the parenchyma and were arranged very regularly between the vascular bundles (Figure 4(c)).

\section{Discussion}

Influence of microrelief and soil conditions on $\mathrm{CH}_{4}$ fluxes

Many tundra ecosystems are characterised by a complicated horizontal structure (Chernov and Matveyeva 1997). Cryogenic processes in permafrost soils lead to the formation of patterned ground with often a pronounced microrelief (French 1996). In the typical polygonal tundra of the central Lena Delta, the microrelief elements of the low-centred polygons and the respective soil and vegetation types are repeated in regular cyclic intervals of 10-30 m. Thus, soil conditions, vegetation characteristics, and consequently $\mathrm{CH}_{4}$ fluxes in polygonal tundra are highly variable on the small scale (decimetres to metres) but rather homogenous on the large scale of $\left(10^{2}\right.$ to $10^{4}$ metres). In order to quantify $\mathrm{CH}_{4}$ emission from tundra ecosystems on the regional scale, it is necessary to characterise the small-scale variability of $\mathrm{CH}_{4}$ emission. During our study, $\mathrm{CH}_{4}$ emission was 6-7 times greater in the depressed polygon centre than emission at the elevated polygon rim. In the Typic Historthel of the polygon centre, a high water table, anoxic conditions in most of the pedon, and high organic matter contents in the anoxic horizons stimulated $\mathrm{CH}_{4}$ production. $\mathrm{CH}_{4}$ emission was much lower at the polygon rim since in the Typic Aquiturbel of the polygon rim the water table was lower, organic matter contents in the anoxic horizons were less, and oxic horizons were more extensive (Table 3). Our results show the importance of the microrelief and the variability of hydrologic conditions as key control factors on $\mathrm{CH}_{4}$ emissions from tundra soils in agreement with other $\mathrm{CH}_{4}$ flux studies (e.g., Svensson and Rosswall 1984; Morrissey and Livingston 1992; Moore and Roulet 1993; Waddington et al. 1996; Grünfeld and Brix 1999). The water table position determines the relative extent of oxic and anoxic horizons within soils and consequently the ratio between $\mathrm{CH}_{4}$ production and $\mathrm{CH}_{4}$ oxidation, the fundamental microbial processes of the $\mathrm{CH}_{4}$ cycle. Beside this direct effect, the water table position influences $\mathrm{CH}_{4}$ fluxes indirectly by affecting soil genesis and vegetation composition, which are important additional control factors on $\mathrm{CH}_{4}$ fluxes.

The $\mathrm{CH}_{4}$ fluxes observed in our study were of the same order of magnitude, albeit slightly lower, as $\mathrm{CH}_{4}$ fluxes reported by other investigators from polygonal tundra in Alaska (Morrissey and Livingston 1992; Christensen 1993) and Northern Siberia (Christensen et al. 1995; Samarkin et al. 1999). Wagner et al. (2003) measured total $\mathrm{CH}_{4}$ fluxes during the complete summer season 1999 at the same low-centred polygon that we chose for our investigations. They observed much higher and more variable $\mathrm{CH}_{4}$ emissions in the polygon centre during July $\left(93 \pm 22 \mathrm{mg} \mathrm{CH}_{4} \mathrm{~m}^{-2} \mathrm{~d}^{-1}\right)$, 
when the water table was distinctly above the soil surface, than in August $\left(25 \pm 7 \mathrm{mg} \mathrm{CH}_{4} \mathrm{~m}^{-2} \mathrm{~d}^{-1}\right)$, when the water table was located a few centimetres below the soil surface. This decrease of $\mathrm{CH}_{4}$ emission was associated by an increase of $\mathrm{CH}_{4}$ oxidation activity in the soils. The effect of the water table position on $\mathrm{CH}_{4}$ emissions from wetlands can be compared with an on-off switch (Christensen et al. 2001). When the water table falls below the soil surface, microbial $\mathrm{CH}_{4}$ oxidation is drastically increased and $\mathrm{CH}_{4}$ emission is reduced. A narrow oxic soil zone can have a high capacity for $\mathrm{CH}_{4}$ oxidation (Whalen et al. 1996).

During our study, temporal variability of $\mathrm{CH}_{4}$ emission was low because the main control factors, water table position and thaw depth, were almost constant during the study period. Temporal fluctuations of soil temperature (Figures 2(c) and 3(c)) appeared to have only a minor effect on $\mathrm{CH}_{4}$ emission. This is in accordance with studies of Svensson and Rosswall (1984), Christensen (1993), and Nykänen et al. (1998). These authors found that $\mathrm{CH}_{4}$ emission correlates with soil temperature only at inundated sites, where the water table is distinctly above the soil surface. If the water table is positioned below the soil surface and $\mathrm{CH}_{4}$ oxidation gains importance, soil temperature is not expected to show a direct effect on $\mathrm{CH}_{4}$ emission. $\mathrm{CH}_{4}$ production has a stronger temperature response with reported $Q_{10}$ values of 2.7-20.5 by comparison with $\mathrm{CH}_{4}$ oxidation with $Q_{10}$ values of only $1.2-$ 2.1 (e.g., Svensson and Rosswall 1984; King and Adamsen 1992; Dunfield et al. 1993; Moosavi and Crill 1998), but the upper soil horizons, where $\mathrm{CH}_{4}$ oxidation occurs, are more exposed to temperature changes than the subsurface horizons of methanogenesis. Thus, it can be assumed that the effect of soil temperature fluctuations on microbial $\mathrm{CH}_{4}$ production is compensated by the temperature effect on $\mathrm{CH}_{4}$ oxidation (Christensen 1993; Whalen et al. 1996).

\section{Effects of vegetation on $\mathrm{CH}_{4}$ fluxes}

Numerous studies demonstrated the importance of the vegetation as a major control factor on $\mathrm{CH}_{4}$ emissions from wetlands (e.g., Schütz et al. 1991; Whiting and Chanton 1992; Grünfeld and Brix 1999; Joabsson et al. 1999; Roura-Carol and Freeman 1999). Tsuyuzaki et al. (2001) found that $\mathrm{CH}_{4}$ emission from grassy marshlands near the Kolyma River in the tundra/taiga transition zone of North-east Siberia was strongly dependent on the vegetation type. At our study site, the strongly differing hydrological conditions within the microrelief of the polygonal tundra caused substantial differences in vegetation cover between the rim and the centre of the polygon. These vegetation differences had a direct effect on the small-scale variability of $\mathrm{CH}_{4}$ emission. Sites in the polygon centre with high densities of $C$. aquatilis culms emitted distinctly more $\mathrm{CH}_{4}$ than sites at the polygon rim with low densities of $C$. aquatilis. The enhancing effect of C. aquatilis on $\mathrm{CH}_{4}$ emission is due to the capability of its aerenchyma to serve as conduits for plant-mediated $\mathrm{CH}_{4}$ transport. Plant-mediated $\mathrm{CH}_{4}$ transport accounted for about two-thirds of the total flux in the polygon centre and for less than one-third of the total at the polygon rim. It is assumed that $C$. aquatilis plants can have an additional positive effect on $\mathrm{CH}_{4}$ emission by providing fresh substrates 
for the methanogenesis as described for several vascular plants by other investigators (Schütz et al. 1991; Whiting and Chanton 1992; Joabsson et al. 1999).

The influence of $C$. aquatilis on $\mathrm{CH}_{4}$ fluxes has to be valued separately for the different microrelief elements of the low-centred polygon. Total $\mathrm{CH}_{4}$ flux (soil + plant flux) was positively correlated to areal density of $C$. aquatilis culms at sites in the polygon centre, while no such relationship could be found at the sites at the polygon rim. At the polygon rim, the presence of $C$. aquatilis culms appeared to have even a small attenuating effect on the total $\mathrm{CH}_{4}$ flux. Previous studies showed that the influence of vascular plants can differ substantially between different sites. Some authors found significant positive correlations between $\mathrm{CH}_{4}$ emission and plant biomass (Morrissey and Livingston 1992; Whiting and Chanton 1992) or culm density (Christensen 1993; Schimel 1995). At other sites, a negative effect of vascular plants on $\mathrm{CH}_{4}$ emission was confirmed (Grünfeld and Brix 1999; RouraCarol and Freeman 1999). At these sites and likewise at our study site at the polygon rim, the stimulation of rhizospheric $\mathrm{CH}_{4}$ oxidation by vascular plants appeared to have a greater effect on $\mathrm{CH}_{4}$ emission than the enhancing effects, that is, plant-mediated $\mathrm{CH}_{4}$ transport and the supply of substrates for methanogenesis.

The plant-mediated proportion of the total $\mathrm{CH}_{4}$ emission from the polygon centre (about 2/3) lay in the same range as results obtained by Schimel (1995) for arctic wet meadow tundra in Alaska, which was characterised by a water table below the soil surface. In inundated tundra wetlands of Alaska, the proportion of plantmediated $\mathrm{CH}_{4}$ transport was reported to be considerably higher with $90-98 \%$ of the total flux (Morrissey and Livingston 1992; Whiting and Chanton 1992; Torn and Chapin 1993). Our results and the comparison with other wetland studies suggest that the effect of plant-mediated $\mathrm{CH}_{4}$ flux is substantially affected by water table position. The effect of plant-mediated $\mathrm{CH}_{4}$ transport is greatest with a high water table and the bulk of roots growing in anoxic soil horizons (Waddington et al. 1996). The lower the water table, the less roots grow within the anoxic $\mathrm{CH}_{4}$ enriched soil horizons and can serve as conduits for $\mathrm{CH}_{4}$ transport to the atmosphere. The better the pore system of a soil is aerated, the bigger is the portion of $\mathrm{CH}_{4}$ that diffuses via the soil pores to the atmosphere. It has to be considered, that diffusion velocity of $\mathrm{CH}_{4}$ is $10^{4}$ times higher in air than in water (Schachtschabel et al. 1998). The dense root exodermes of $C$. aquatilis have an even higher diffusion resistance than water (Končalová 1990). Thus, a substantial $\mathrm{CH}_{4}$ diffusion from the pore waters into the root aerenchyma through the exodermes only happens when a high $\mathrm{CH}_{4}$ concentration gradient between pore waters and root aerenchyma is present and the diffusion via the soil pore system is hampered by water saturation.

\section{Mechanism of gas transport via $\mathrm{C}$. aquatilis}

The microscopic-anatomical studies showed that large aerenchyma are present in the vegetative organs of $C$. aquatilis that can act as pathways of facilitated diffusion for $\mathrm{CH}_{4}$ produced in anoxic soil horizons. Many monocotyledonous wetland plants develop aerenchyma as adaptation to soil waterlogging. The internal air spaces 
provide a conduit for oxygen from the atmosphere to the roots and for $\mathrm{CH}_{4}$ in the opposite direction. Particularly, the $\mathrm{CH}_{4}$ transport processes in large emergent and floating wetland plants like Phagmites australis, Typha latifolia, or Nuphar lutea are thoroughly investigated (e.g., Große et al. 1991; Tornbjerg et al. 1994; Armstrong et al. 1996). In these plants, gas transport by pressure-induced convection could be verified. The exact mechanism of plant-mediated $\mathrm{CH}_{4}$ flux through smaller monocotyledonous plants as sedges and grasses is more uncertain, although it was addressed by several studies in the last decade (Morrissey et al. 1993; Schimel 1995; Kelker and Chanton 1997; King et al. 1998).

The results of our clipping experiment suggest that plant-mediated $\mathrm{CH}_{4}$ transport via $C$. aquatilis plants is driven only by facilitated diffusion. A pressure-induced active transport should have broken down after clipping. Furthermore, the experiment indicated that diffusion was not limited by the diffusion resistance of the aboveground portion of Carex plants but rather by a high diffusion resistance at the transition between the rhizosphere and the root aerenchyma. This conclusion was backed by the microscopic-anatomical studies of Carex roots: dense exodermes, that were built up of compactly packed hexagonal cells with thick cell walls, separated the root aerenchyma from the rhizosphere. Such exodermes act as effective diffusion barriers and reduce oxygen loss into the rhizosphere as well as $\mathrm{CH}_{4}$ infiltration into the root aerenchyma (Končalová 1990; Schütz et al. 1991). In contrast to our results, Morrissey et al. (1993) and Schimel (1995) observed that the $\mathrm{CH}_{4}$ release from arctic Carex-dominated wetlands was limited by the above-ground portion of the plant, that is, by stomatal control. On the other hand, Kelker and Chanton (1997) observed no clear and enduring increase of $\mathrm{CH}_{4}$ flux after clipping sedges in a boreal fen and concluded that plant-mediated gas transport through Carex plants had to be regulated below ground, as is common among most other plant species (Armstrong 1979; Chanton and Dacey 1991). The different results between studies can be due to differences in factors other than leaf or root resistance, such as plant phenology, $\mathrm{CH}_{4}$ concentration in pore waters of the respective soil, microclimate, or root uptake controlled by soil temperature (Morrissey et al. 1993). These factors should be considered in a more detailed continuative study to improve the understanding of plant-mediated $\mathrm{CH}_{4}$ transport by $C$. aquatilis in tundra ecosystems.

\section{Perspectives}

A multi-year study on the seasonal and interannual variability of $\mathrm{CH}_{4}$ emission is in progress at the described polygonal tundra. Longer time series are needed to accurately quantify the impacts of environmental controls on $\mathrm{CH}_{4}$ emission, as water table, soil temperature, thaw depth, or plant phenology. Beside the moist and wet soils, which were investigated in the presented study, polygonal ponds are an important landscape feature of polygonal tundra. The $\mathrm{CH}_{4}$ dynamics of theses ponds shall be studied in detail in the future. The relative areal extent of the ponds and the different soils shall be evaluated by the analysis of high-resolution remote sensing data to allow a reasonable regional quantification of $\mathrm{CH}_{4}$ emission by upscaling. 


\section{Conclusions}

The presented study points out the high small-scale spatial variability of $\mathrm{CH}_{4}$ fluxes in the polygonal tundra of the Lena Delta, Northern Siberia. The pronounced microrelief of polygonal tundra induces strongly differing hydrologic conditions within short distances that affect aeration status and organic matter content of soils as well as the vegetation cover. $\mathrm{CH}_{4}$ emission is controlled by all these interdependent factors in a complex way. Beside water table position, the vegetation cover is of great importance in controlling $\mathrm{CH}_{4}$ emission from polygonal tundra. It was shown that the dominant vascular plant of the study area, $C$. aquatilis, possesses large aerenchyma, which serve as pathways for substantial plant-mediated $\mathrm{CH}_{4}$ transport. The importance of plant-mediated $\mathrm{CH}_{4}$ flux is strongly influenced by the position of the water table relative to the main root horizon. Plant-mediated $\mathrm{CH}_{4}$ transport accounted to about two-thirds of the total flux in the polygon centre and to less than one-third of the total flux at the polygon rim. The effect of plant-mediated $\mathrm{CH}_{4}$ transport is greatest with a high water table and the bulk of roots growing in anoxic soil horizons. A clipping experiment and microscopic-anatomical studies suggested that plantmediated $\mathrm{CH}_{4}$ transport via $C$. aquatilis plants is driven only by diffusion and is limited by the high diffusion resistance of the dense root exodermes.

\section{Acknowledgements}

We thank the Russian-German parties of the expedition Lena 1999 (Holger Becker, Alexander Vlasenko, Björn Schulz, Anja Kurchatova) for the pleasant team work in the field. Special thanks go to Marco Schmidt at the Institute of General Botany, University of Hamburg, for assistance with the electron scanning microscopy, Susanne Kopelke and Professor Horst Wiechmann at the Institute of Soil Science, University of Hamburg, for providing support in the laboratory and advice in the planning of this work, and the staff of the Alfred Wegener Institute, Research Unit Potsdam, for making the expedition to the Lena Delta possible. We appreciate helpful comments on this manuscript from Christian Wille and the two reviewers.

This work was conducted within the framework of the German-Russian joint project 'System Laptev Sea 2000' (03G0534G), which was financed by the German Federal Ministry of Education and Research.

\section{References}

Armstrong W. 1979. Aeration in higher plants. In: Woolhouse H.W. (ed) Advances in Botanical Research. Academic Press, New York, pp. 226-333.

Armstrong J., Armstrong W., Beckett P.M., Halder J.E., Lythe S., Holt R. and Sinclair A. 1996. Pathways of aeration and the mechanisms and beneficial effects of humidity - and Venturi-induced convections in Phragmites australis (Cav.) Trin. ex Steud. Aquat. Bot. 54: 177-197.

Braun-Blanquet J. 1964. Pflanzensoziologie. Springer, Wien.

Cao M., Marshall S. and Gregson K. 1996. Global carbon exchange and methane emissions from natural wetlands: application of a process-based model. J. Geophys. Res. 101(D9): 14399-14414. 
Chanton J.P. and Dacey J.W.H. 1991. Effects of vegetation on methane flux, reservoirs, and carbon isotopic composition. In: Sharkey T.D., Holland E.A. and Mooney H.A. (eds) Trace Gas Emissions by Plants. Academic Press, San Diego, pp. 65-89.

Chernov Y.I. and Matveyeva N.V. 1997. Arctic ecosystems in Russia. In: Wielgolaski F.E. (ed) Polar and Alpine Tundra - Ecosystems of the World 3. Elsevier, Amsterdam, pp. 361-507.

Christensen T.R. 1993. Methane emission from arctic tundra. Biogeochemistry 21: 117-139.

Christensen T.R., Jonason S., Callaghan T.V. and Havström M. 1995. Spatial variation in high-latitude methane flux along a transect across Siberian and European tundra environments. J. Geophys. Res. 100(D10): 21035-21045.

Christensen T.R., Lloyd D., Svensson B., Martikainen P., Harding R., Oskarsson H., Friborg T., Søgaard H. and Panikov N. 2001. Biogenic controls on trace gas fluxes in northern wetlands. IGBP-Global Change NewsLetter 51: 9-15.

Dunfield P., Knowles R., Dumont R. and Moore T.R. 1993. Methane production and consumption in temperate and subarctic peat soils: response to temperature an $\mathrm{pH}$. Soil Biol. Biochem. 25(3): 321-326.

Elovskaya L.G. 1987. Classification and diagnostics of Yakutian permafrost soils. Yakutian Section of the Siberian Branch of the Academy of Science USSR, Yakutsk.

French H.M. 1996. The Periglacial Environment. Longman Singapore Publishers, Singapore.

Große W., Büchel H.B. and Tiebel H. 1991. Pressurized ventilation in wetland plants. Aquat. Bot. 39: 89-98.

Grünfeld S. and Brix H. 1999. Methanogenesis and methane emissions: effects of water table, substrate type and presence of Phragmites australis. Aquat. Bot. 64: 63-75.

Harriss R.C., Bartlett K., Frolking S. and Crill P. 1993. Methane emissions from northern high-latitude wetlands. In: Oremland R.S. (ed) Biogeochemistry of Global Change: Radiaoactively Active Trace Gases. Chapman and Hall, New York, pp. 449-485.

Heyer J. and Suckow R. 1985. Ökologische Untersuchungen der Methanoxydation in einem sauren Moorsee. Limnologica 16(2): 247-266.

Holzapfel-Pschorn A., Conrad R. and Seiler W. 1986. Production, oxidation and emission of methane in rice paddies. FEMS Microbiol. Ecol. 31: 343-351.

Intergovernmental Panel of Climate Change 2001. Climate Change 2001: Impacts, Adaptation, and Vulnerability. Cambridge University Press, Cambridge.

Joabsson A., Christensen T.R. and Wallén B. 1999. Influence of vascular plant photosynthetic rate on $\mathrm{CH}_{4}$ emission from peat monoliths from southern boreal Sweden. Polar Res. 18: 215-220.

Kelker D. and Chanton J. 1997. The effect of clipping on methane emissions from Carex. Biogeochemistry 39: $37-44$.

King G.M. and Adamsen A.P.S. 1992. Effects of temperature on methane consumption in a forest soil and in pure cultures of the methanotroph Methylomonas rubra. Appl. Env. Microbiol. 58(9): 2758-2763.

King J.Y., Reeburgh W.S. and Regli S.K. 1998. Methane emission and transport by arctic sedges in Alaska: results of a vegetation removal experiment. J. Geophys. Res. 103(D22): 29083-29092.

Končalová H. 1990. Anatomical adaptations to waterlogging in roots of wetland graminoids: limitations and drawbacks. Aquat. Bot. 38: 127-134.

Matveyeva N.V. 1994. Floristic classification and ecology of tundra vegetation of the Taymyr Peninsula, northern Siberia. J. Veg. Sci. 5: 813-828.

Maxwell B. 1997. Recent climate patterns in the Arctic. In: Oechel W.C., Callaghan T., Gilmanov T., Holten J.I., Maxwell B., Molau U. andSveinbjö rnsson B. (eds) Global Change and Arctic Terrestrial Ecosystems. Springer, New York, pp. 21-46.

Moore T.R. and Roulet N.T. 1993. Methane flux: water table relations in northern wetlands. Geophys. Res. Lett. 20: 587-590.

Moosavi S.C. and Crill P.M. 1998. $\mathrm{CH}_{4}$ oxidation by tundra wetlands as measured by a selective inhibitor technique. J. Geophys. Res. 103(D22): 29093-29106.

Morrissey L.A. and Livingston G.P. 1992. Methane emissions from Alaska arctic tundra: an assessment of local spatial variability. J. Geophys. Res. 97: 16661-16670. 
Morrissey L.A., Zobel D.B., Livingston G.B. 1993. Significance of stomatal control on methane release from Carex dominated wetlands. Chemosphere 26(1-4): 339-355.

Müller K. 1997. Patterned ground and properties of permafrost soils of the Northsiberian Lena Delta. J. Plant Nutr. Soil Sci. 160: 497-503.

Nakano T., Kuniyoshi S. and Fukuda M. 2000. Temporal variation in methane emission from tundra wetlands in a permafrost area, northeastern Siberia. Atmos. Environ. 34: 1205-1213.

Nykänen H., Alm J., Silvola J., Tolonen K. and Martikainen P.J. 1998. Methane fluxes on boreal peatlands of different fertility and the effect of long-term experimental lowering of the water table on flux rates. Global Biogeochem. Cycles 12: 53-69.

Panikov N.S., Belyaev A.S., Semenov A.M., Zelenev V.V. 1993. Methane production and uptake in some terrestrial ecosystems of the former USSR. In: Oremland R.S. (ed) Biogeochemistry of Global Change: Radioactively Active Trace Gases. Chapmann and Hall, New York, pp. 221-244.

Popp T.J., Chanton J.P., Whiting G.J. and Grant N. 2000. Evaluation of methane oxidation in the rhizosphere of a Carex dominated fen in north central Alberta, Canada. Biogeochemistry 51: 259-281.

Rachold V. andGrigoriev M.N. (eds) 2000. Russian-German Cooperation SYSTEM LAPTEV SEA 2000: The Expedition LENA 1999. Reports on Polar Research 354: 1-269.

Roulet N.T., Jano A., Kelly C.A., Klinger L.F., Moore T.R., Protz R., Ritter J.A. and Rouse W.R. 1994. Role of the Hudson bay lowland as a source of atmospheric methane. J. Geophys. Res. 99(D1): $1435-1454$.

Roura-Carol M. and Freeman C. 1999. Methane release from peat soils: effects of Sphagnum and Juncus. Soil Biol. Biochem. 31: 323-325.

Samarkin V.A., Gundelwein A. and Pfeiffer E.-M. 1999. Studies of methane production and emission in relation to the microrelief of a polygonal tundra in northern Siberia. In: Kassens H., Bauch H.A., Dmitrenko I.A. et-al (eds) Land-Ocean Systems in the Siberian Arctic, Dynamics and History.Springer,Berlin, pp. 329-342.

Schachtschabel P., Blume H.-P., Brümmer , Hartge K.-H. and Schwertmann U. 1998. Scheffer/ Schachtschabel - Lehrbuch der Bodenkunde. Enke, Stuttgart.

Schlichting E., Blume H.P. and Stahr K. 1995. Bodenkundliches Praktikum - Pareys Studientexte 81. Blackwell Wissenschaftsverlag, Berlin.

Schoeneberger P.J., Wysocki D.A., Benham E.C. and Broderson W.D. 1998. Field Book for Describing and Sampling Soils. Natural Resources Conservation Service, USDA, National Soil Survey Center, Lincoln.

Schütz H., Schröder P. and Rennenberg H. 1991. Role of plants in regulating the methane flux to the atmosphere. In: Sharkey T.D., Holland E.A. and Mooney H.A. (eds) Trace Gas Emissions by Plants. Academic Press, San Diego, pp. 29-63.

Sebacher D.J., Harriss R.C. and Bartlett K.B. 1985. Methane emissions to the atmosphere through aquatic plants. J. Environ. Qual. 14: 39-46.

Seibt A., Hoth P. and Naumann D. 2000. Gas solubility in formation waters of the North German Basin implications for geothermal energy recovery. In: Proceedings World Geothermal Congress 2000, Kyushu-Tohoku, Japan, 28 May - 10 June 2000. International Geothermal Association IGA, Pisa, Italy, pp. 1713-1718.

Schimel J.P. 1995. Plant transport and methane production as controls on methane flux from arctic wet meadow tundra. Biogeochemistry 28: 183-200.

Soil Survey Staff, Soil Conservation Service, USDA 1998. Keys to Soil Taxonomy 8th edn. Pocahontas, Blacksburg, Virginia.

Sorrel B.K. and Boon P.I. 1994. Convective gas flow in Eleocharis sphacelata R.Br.: methane transport and release from wetlands. Aquat. Bot. 47: 197-212.

Svensson B.H. and Rosswall T. 1984. In situ methane production from acid peat in plant communities with different moisture regimes in a subarctic mire. Oikos 43: 341-350.

Thomas K.L., Benstead J., Davies K.L. and Lloyd D. 1996. Role of wetland plants in the diurnal control of $\mathrm{CH}_{4}$ and $\mathrm{CO}_{2}$ fluxes in peat. Soil Biol. Biochem. 28: 17-23.

Tsuyuzaki S., Nakano T., Kuniyoshi S. and Fukuda M. 2001. Methane flux in grassy marshlands near Kolyma River, north-eastern Siberia. Soil Biol. Biochem. 33: 1419-1423. 
Torn M.S. and Chapin F.S. 1993. Environmental and biotic controls over methane flux from arctic tundra. Chemosphere 26: 357-368.

Tornbjerg T., Bendix M. and Brix H. 1994. Internal gas transport in Typha latifolia L. and Typha angustifolia L. 2. Convective throughflow pathways and ecological significance. Aquat. Bot. 49: 91-105.

Van der Nat F.-J.W.A. and Middelburg J.J. 1998. Seasonal variation in methane oxidation by the rhizosphere of Phragmites australis and Scirpus lacustris. Aquat. Bot. 61(2): 95-110.

Waddington J.M., Roulet N.T. and Swanson R.V. 1996. Water table control of $\mathrm{CH}_{4}$ emission enhancement by vascular plants in boreal peatlands. J. Geophys. Res. 101: 22775-22785.

Wagner D., Kobabe S., Pfeiffer E.-M. and Hubberten H.-W. 2003. Microbial controls on methane fluxes from a polygonal tundra of the Lena Delta, Siberia. Permafrost Periglacial Processes 14: 173-185.

Whalen S.C. and Reeburgh W.S. 1992. Interannual variations in tundra methane emission: a 4-year time series at fixed sites. Global Biogeochem. Cycles 6: 139-159.

Whalen S.C., Reeburgh W.S. and Reimers C.E. 1996. Control of tundra methane emission by microbial oxidation. In: Reynolds J.F. and Tenhunen J.D. (eds) Landscape Function and Disturbance in Arctic Tundra, Ecological Studies 120. Springer, Berlin, Germany, pp. 257-274.

Whiting G.J. and Chanton J.P. 1992. Plant-dependent $\mathrm{CH}_{4}$-emission in a subarctic Canadian fen. Global Biogeochem. Cycles 9: 225-231

Yamamoto S., Alcauskas J.B. and Crozier T.E. 1976. Solubility of methane in distilled water and seawater. J. Chem. Eng. Data 21(1): 78-80. 